YEARBOOK

of ANTITRUST

and REGULATORY

STUDIES

www.yars.wz.uw.edu.pl
Peer-reviewed scientific periodical, focusing on legal and economic issues of antitrust and regulation. Creative Commons Attribution-No Derivative Works 3.0 Poland License.

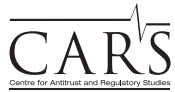

Centre for Antitrust and Regulatory Studies, University of Warsaw, Faculty of Management www.cars.wZ.uw.edu.pl

\title{
Evaluation of Pre-accession State Aid in the Energy Sector. Case Comment to the Judgment of the Court of Justice of 1 October 2015 \\ Electrabel SA, Dunamenti Erömü Zrt. v European Commission (Case C-357/14 P)
}

\author{
by
}

Tihamér Tóth*

\section{CONTENTS}

I. Introduction

II. The background of the case: the privatization of the Hungarian electricity sector

III. The Commission decision on illegal State aid

IV. The Judgment of the Court of Justice

1. Non-admissibility: the limits of the concept of an "undertaking"

2. Evaluating pre-accession State aid - the legal framework

3. Evaluating pre-accession State aid - the reference date for applying the MEIP test

4. Absence of an advantage during the privatization

5. The subject of the recovery order

6. Other related litigations: the ICSID dispute and actions for damages

7. Evaluation of the case

* Assistant professor, Pázmány Péter Catholic University, of counsel Réczicza Dentons Europe LLP; Tihamer.Toth@dentons.com. Article received: 20 July 2016; accepted: 18 October 2016.

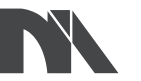

The creation of the English-language version of these publications is financed in the framework of contract No. 768/P-DUN/2016 by the Ministry of Science and Higher Education committed to activities aimed at the promotion of education. 
Key words: power purchase agreements; pre-accession state aid; recovery of unlawful state aid; energy market; concept of an undertaking; MEIP test - lack of advantage; ICSID procedure; Energy Charter Treaty.

JEL: K23; K32; K41

\section{Introduction}

The European Commission decided in 2008 that Hungary provided State aid through a set of Power Purchase Agreements ${ }^{1}$. Electrabel SA (hereinafter, Electrabel) and Dunamenti Erőmű Zrt. (hereinafter, Dunamenti Erőmű) brought an action for annulment against this decision that was dismissed by the General Court in 2014². One year later, the Court of Justice confirmed the first instance ruling, even though Advocate General Wathelet was of the opinion that the contested judgment should be set aside.

According to the Advocate General (hereinafter, AG), the case raised three difficult issues: (i) is the relevant date for the assessment of the existence of the aid the date on which the measure was implemented (well before Hungary's EU accession) or the date of the accession; (ii) should the date of accession be the relevant date, do facts prior to that date have to be included in the assessment of the existence of State aid, and (iii) which company should repay the aid granted ${ }^{3}$.

\section{The background of the case: the privatization of the Hungarian electricity sector}

Dunamenti Erőmű is a Hungarian electricity generator which operates a power plant in the proximity to Budapest. As a former public undertaking, the company was privatized in 1995. Electrabel SA (part of the GDF Suez group) became its majority owner; Magyar Villamos Művek Zrt. (hereinafter, MVM), now the key Hungarian public undertaking in the electricity sector, owned $25 \%$ of its shares.

\footnotetext{
1 NN 49/2005, Brussels, 2008.VI.04 C (2008) 2223 final, available at: http://ec.europa.eu/ competition/state_aid/cases/201965/201965_827719_388_1.pdf (20.07.2016).

2 Case T-179/09 Dunamenti Erömü v Commission, ECLI:EU:T:2014:236.

3 Case C-390/98 H.J. Banks \& Co. Ltd $v$ The Coal Authority and Secretary of State for Trade and Industry, ECLI:EU:C:2001:456, and C-277/00 Germany v Commission, ECLI:EU:C:2004:238.
} 
The facts of the case date back to the mid 1990s. At that time, the most urgent policy objectives included: to achieve supply security, to modernize infrastructure, and to meet environmental protection standards. The socialistliberal government that came into power in 1994 decided that these aims could only be attained with the involvement of foreign investors. The State thus sold the country's most important electricity producers and distributors, with the exception of the nuclear power plant and the high voltage transmission grid.

Hungary thus attracted huge foreign investments. However, all this came at a price. Foreign investors were reluctant to commit themselves without longterm power purchase agreements (hereinafter, PPAs), with MVM purchasing power generated at a price calculated according to a formula included in the privatization deal. Moreover, the PPAs enabled MVM to fulfil its obligation of ensuring supply security in the entire country. Twenty such agreements were concluded between 1995 and 2001, ten of which were subject to the decision ${ }^{4}$ of the European Commission (hereinafter, EC or Commission) subject to the appeal proceedings culminating in the reviewed judgment.

The PPAs reserved for MVM all, or a substantial part of the generation capacities of the power plants covered by the agreements. At the same time, MVM was required to purchase a specific minimum quantity of electricity from each power plant operated under a PPA at prices fixed in the PPAs according to the set formula. Starting from 1 January 2004, the rules provided for the introduction of, first, a capacity fee for the reserved capacities in order to pay for the making available of that capacity, that fee covered fixed costs and the cost of capital, including profit, being paid by MVM, and, second, an electricity fee to be paid for the guaranteed minimum off-take, which covered variable costs. Even if MVM did not purchase the fixed minimum quantity, it had to pay for the fuel costs incurred.

The PPA between Dunamenti Erőmű and MVM entered into force in 1996. It was to continue until 2010 with respect to the gas-fired "F block", and until 2015 with respect to the "G2 block", a combined cycle gas turbine unit. Just two months after the conclusion of the PPA, Electrabel acquired Dunamenti Erőmü from the Hungarian State following a competitive public tendering procedure. The agreement made the State-owned MVM acquire about $75 \%$ of Dunamenti's electricity production.

Until 2002, the Hungarian electricity market had not been liberalized, only privatized. The vertically integrated MVM acted as a single buyer. Electricity generators could supply energy directly only to MVM and the latter was the only company authorized to sell electricity to regional distribution companies. At the time when Hungary finally joined the EU, Hungary had a dual market

4 The European Commission (EC) did not challenge agreements that ceased to exist before Hungary's EU accession. 
in electricity. The public utility sector accounted for approximately $70 \%$ of power generation, the competitive sector accounted for about $30 \%$. In the public utility sector, MVM was still the only wholesaler. MVM was also selling surplus electricity purchased under the PPAs (that is, electricity not needed in the public utility sector) in the competitive sector. This interim regime was in place between January 2003 and January 2008.

The PPAs covered about $2 / 3$ of the Hungarian electricity production. As a result, even if price regulation was abolished in 2003, wholesale prices were not influenced by market trends but rather, by the effects of the PPAs.

\section{The Commission decision on illegal State aid}

On 4 June 2008, the Commission adopted a decision finding that the PPAs conferred illegal State aid within the meaning of Article 87(1) EC (now 101(1) TFEU) on Hungarian electricity generators and that this State aid was incompatible with the common market. The State aid resulting from the PPAs consisted of the fact that MVM was obliged to purchase a certain capacity and a guaranteed minimum quantity of electricity at a price covering capital, fixed costs and variable costs over a significant part of the lifetime of the generating units, thereby guaranteeing a return on investment to the generators. The Commission believed that at the time of Hungary's EU accession, no rational market economy investor would have entered into such an agreement. Bearing all the risks of fluctuating fuel prices, disregarding market trends, and the extended length of time of the agreements, was not in line with competitive market circumstances 5 . Accordingly, the EC ordered that the aid should be terminated within six months and obliged Hungary to recover it from the beneficiaries within ten months starting from 1 May 2004.

Hungary did not challenge the decision but complied by adopting a new law terminating the PPAs effective starting from 31 December 2008. In the end, no aid was recovered from the beneficiaries because the government decided to put in place a stranded costs compensation scheme, as foreseen by a Commission communication acknowledging that certain losses caused by market liberalization can be levelled by the State ${ }^{6}$. Since Dunamenti Erőmü's

5 According to the EC, in 2006, prices under the PPAs were 15-135\% higher than prices in the liberalized market albeit admittedly comparing historic PPA prices with those existing in other Member States is not an easy exercise.

${ }^{6}$ Commission Communication relating to the methodology for analysing State aid linked to stranded costs, available at http://ec.europa.eu/competition/state_aid/legislation/stranded_costs_ en.pdf (20.07.2016). Under the scheme, stranded costs correspond to the difference between 
stranded costs were higher than the aid they were to pay back to the State, there was no recovery in real terms.

Dunamenti Erőmü challenged the findings of the Commission on the existence of the State aid, on its classification as "new aid", as well as on the identification of the relevant date to assess the aid. The plaintiff disputed also the way in which the Commission applied the market economy investor principle (hereinafter, MEIP) test and alleged a breach of the principles of the protection of legitimate expectations and of legal certainty. The company argued furthermore that the aid contained in the PPA was not an operating aid, but rather an investment aid.

In the judgment under appeal, adopted on April 2014, the General Court (hereinafter, GC) rejected all pleas in law raised by the plaintiff. Interestingly, it took the first instance court five years to adjudicate all the arguments raised by the plaintiff. The procedure before the Court of Justice (hereinafter, CJ) was far shorter.

\section{The Judgment of the Court of Justice}

\section{Non-admissibility: the limits of the concept of an "undertaking"}

The judgment covered an interesting procedural issue. According to the second paragraph of Article 56 of the Statute of the Court of Justice of the European Union (hereinafter, CJEU), an appeal against a judgment of the GC may be brought by "any party which has been unsuccessful, in whole or in part, in its submissions". The Commission decision was formally challenged only by Dunamenti Erőmű, while the judgment of the GC was also appealed by Electrabel. This was because when the action against the contested decision was brought before the GC, Electrabel and Dunamenti Erőmű were both members of the same entity - the GDF group. However, in June 2014, Electrabel sold its shareholding in Dunamenti Erőmü.

AG Wathelet argued that Electrabel's action should be dismissed on this basis, seeing as it was not a party to the proceedings before the General Court. The CJ agreed by pointing out that preventing Electrabel from bringing the appeal does not in any way infringe its right of access to justice or the principle of good administration ${ }^{7}$. The precise identification of persons capable of

the investment costs of each of the beneficiaries and their operating profits, both historic (from the date of entry into force of the PPAs to their early termination) and projected (between the date of early termination and the expiry dates of the PPAs as initially stipulated).

7 Judgment, para. 31. 
bringing an appeal before the CJEU in a given case, as laid down in Article 56 of the Statute, is precisely to safeguard the proper administration of justice. As a result, the CJ dealt only with the pleas submitted by Dunamenti Erőmü.

\section{Evaluating pre-accession State aid - the legal framework}

State measures put into effect before EU accession but still applicable after that accession, and which can be regarded as State aid under Article 107(1) TFEU at the date of that accession, are subject to the specific rules set out in Annex IV to the Act of Accession. These measures are classified as new aid unless they fall within one of three categories: (i) aid measures put into effect before 10 December 1994, (ii) aid measures expressly listed in the Appendix to Annex IV, and (iii) aid measures which prior to the date of accession were assessed by the State aid monitoring authority of Hungary and found to be compatible with aquis, and to which the Commission did not raise an objection pursuant to a special procedure.

The GC agreed with the Commission that the PPA at hand did not fall within any of the three aforementioned categories. The PPA was not implemented before 10 December 1994, it was not listed in the appendix to Annex IV, and it was not assessed by the Hungarian State aid monitoring authority prior to the date of its EU accession and found to be compatible with aquis, with no objection being raised towards it by the Commission.

It should be noted that the Act of Accession changed previous law on this subject whereby aid introduced before the Treaty came into force, or before the accession of the Member State concerned to the European Union, had to be regarded as existing aid ${ }^{8}$.

\section{Evaluating pre-accession State aid - the reference date for applying the MEIP test}

The EC decision, as confirmed by the GC, took the date of Hungary's EU accession, 1 May 2004, as the relevant date for the assessment of whether the PPAs constituted State aid.

Dunamenti Erőmű argued that the GC erred in law by taking the date of Hungary's EU accession as the date of reference for the determination of whether the PPA constituted State aid. Dunamenti Erőmú added that it is illogical and incorrect in law to apply the concepts of "advantage" and

8 Judgment of the ECJ of 15.03.1994, Case C-387/92 Banco Exterior de España, ECLI:EU:C:1994:100, para. 19. 
"private investor" to a date where no investment had been made 9 . The plaintiff submitted that the date on which the PPA had in fact been granted (that is to say, December 1995) should have been taken as the date of reference. Where, as in the present case, the measure in question remained applicable at the time of accession, the reference date serves to identify the moment at which it is necessary to assess whether the measure constituted State aid. However, taking the date of accession as the reference date does not in itself automatically mean that matters prior to that date cannot be taken into account ${ }^{10}$.

AG Wathelet emphasized that the position of a hypothetical market operator, like the Hungarian State, should be analysed on the date when the investment decision had been made, taking thus into account the circumstances prevailing in 1995. "If, in the context of applying the private investor test, it is necessary to ask the question whether, at the time of accession, a hypothetical market operator would have acted in the same way as the State had acted, then the relevant factual circumstances which dictated the grant of the aid measure at issue cannot be excluded solely because they precede accession, since that would place the State and the hypothetical market operator in situations that are not comparable, which could obviously lead them to take different decisions"11.

AG Wathelet noted also that this approach is in line with the Commission's own practice when it systematically takes into account, in its assessment of the existence of aid, factual circumstances prior to the date of the new Member State's EU accession. In another Hungarian case, the Postabank Decision No. 2009/174, the Commission stated that "[w]hen assessing the action of the Hungarian authorities in the light of the market economy investor principle in 2003, it has to be noted that the Commission does not question the way Postabank was privatised and acknowledges that it was sold to the highest bidder under an open competitive tender procedure" 12 .

The AG thus concluded that by rejecting Dunamenti Erőmü's arguments regarding the Commission's refusal to take into account the intrinsic link between the PPA and its privatisation when reviewing the Commission's application of the private investor test solely because that factor preceded Hungary's EU

9 Judgments in France v Commission (Case C-482/99, ECLI:EU:C:2002:294, paras 71 and 76 to 83); Westdeutsche Landesbank Girozentrale and Land Nordrhein-Westfalen v Commission (Cases T-228/99 and T-233/99, ECLI:EU:T:2003:57, para. 246), and Netherlands $v$ Commission (Cases T-29/10 and T-33/10, ECLI:EU:T:2012:98, para. 78), noting that the private investor analysis should be based on the circumstances prevailing at the date of adoption of the measure concerned.

10 Opinion, 113-114.

11 Opinion, 121.

12 2009/174/EC of 21 October 2008 on measure C 35/04 implemented by Hungary for Postabank and Takarékpénztár Rt./Erste Bank Hungary Nyrt. (OJ L 62, 6.03.2009, p. 14). 
accession, the GC erred in law and, in that respect, its judgment should be set aside. AG Wathelet suggested also that the proper application of the MEIP test is not a matter for the judiciary, the Commission decision should thus be annulled in so far as it concerns Dunamenti Erőmü. The proper application of the MEIP test involves a complex economic assessment and the judiciary must not substitute (its) own economic assessment for that of the Commission ${ }^{13}$.

The CJ did not follow the advice of its Advocate General. The CJ's reasoning started by recalling that European State aid rules became mandatory in Hungary on 1 May 2004, the date of its EU accession. Furthermore, Hungary accepted that aid measures still applicable after that date had to be examined in the light of EU State aid rules, if those measures could not be classified as existing aid in accordance with the provisions of that act.

The CJ, after recalling the wording of implementing Regulation 659/199914 and its own judgment in Kremikovtzi ${ }^{15}$, concluded that the date of Hungary's EU accession is the date on which an aid measure still applicable after that date must be assessed. The GC was thus correct to hold ${ }^{16}$ that if the approach advocated by Dunamenti Erőmű was to be accepted, the Commission could not review any measure adopted before the date of accession, which did not constitute State aid at that time but which, subsequently, became State aid and remained so after that date ${ }^{17}$.

Interestingly, the $\mathrm{CJ}$ refused to consider arguments relating to the practice of the Commission. It emphasized that the practice followed by the EC in its decisions or its guidelines cannot bind the CJ in its interpretation of EU rules relating to State aid $^{18}$.

13 Order in DSG v Commission (Case C-323/00 P, ECLI:EU:C:2002:260, para. 43). See also Spain v Lenzing (Case C-525/04 P, ECLI:EU:C:2007:698, para. 57).

14 Council Regulation (EC) No. 659/1999 of 22 March 1999 laying down detailed rules for the application of Article 93 of the EC Treaty (OJ L 83, 27.03.1999, p. 1). According to Article 1(b)(v), aid is deemed to be an existing aid because it can be established that at the time when it was put into effect it did not constitute an aid, and subsequently it became an aid due to the evolution of the common market and without having been altered by the Member State. Para. 54 provides that only as from the time of accession that, in Bulgaria, the criteria laid down in Article 87(1) EC may be directly applied as such, and then only in respect of situations that arise on or after that date.

15 Case C-262/11, ECLI:EU:C:2012:760, paras 2 and 3, according to which measures implemented before the accession of the Republic of Bulgaria to the European Union, but which, first, are still applicable post-accession and, second, satisfy the cumulative requirements of Article 87(1) EC on the date of accession, are subject to the specific rules laid down in Annex $\mathrm{V}$ to the 2005 Act of Accession.

16 Judgment of the GC, para. 65.

17 This was the case here since previous state measures started to have effects on the internal market only after the market was liberalized.

18 Para. 68. 


\section{Absence of an advantage during the privatization}

According to Dunamenti Erőmű, when analysing whether the PPA had given an advantage to foreign investors, the privatisation and its context should have been taken into account, since the PPA was a pre-privatisation measure. MVM acted as a private investor when it entered into that agreement. Also, the State acted as a private investor seeking to maximise the financial outcome of the sale of Dunamenti Erőmű. Even if the PPA had entailed an advantage, the acquisition of Dunamenti Erőmű by Electrabel in the course of a tendering procedure eliminated any alleged advantages.

On the other hand, the Commission argued that the absence of an advantage to the purchaser does not exclude the presence of an advantage to the purchased business, irrespective of the fact that the shares or the assets of the undertaking were purchased ${ }^{19}$. Even if the purchaser, in this case Electrabel, pays a market price for it, and thus does not itself benefit from aid, this fact is not relevant to the assessment of whether the purchased entity received aid. The EC did not take into account events that occurred a decade before Hungary's EU accession, the link between the privatization and the PPA was disregarded by the Commission.

The GC refused to consider Dunamenti Erőmü's arguments that the aid had been repaid by Electrabel on the ground that the change in share ownership had taken place before Hungary's EU accession ${ }^{20}$.

The CJ agreed with the GC's finding that the plaintiffs' arguments cannot demonstrate that that PPA, as applied from 1 May 2004 onwards, did not confer an advantage on Dunamenti Erőmű. The question as to whether that agreement contained State aid compatible with the common market on the date of its conclusion or on any other date prior to Hungary's EU accession is of no relevance for the determination whether that agreement contained State aid on the accession date. The arguments relating to the sale of Dunamenti Erőmü to Electrabel cannot be accepted either, since the State aid is not a consequence of the sale itself but stems from the PPA, as applied from 1 May 2004 onwards $^{21}$.

The CJ recalled that when applying the private investor test, the Commission has a duty to carry out a global assessment of the aid measure at hand, according to the information available and developments foreseeable at the time when the decision to grant that aid was taken. Information on events

19 Judgments in Elliniki Nafpigokataskevastiki and Others $v$ Commission (Case T-384/08, ECLI:EU:T:2011:650, paras 66 to 68), and Commission v Scott (Case C-290/07 P, ECLI:EU:C:2010:480, paras 5 to 11, 25 and 26).

${ }^{20} \mathrm{GC}$, paras 68 and 69.

21 Paras 94-95. 
which occurred prior to the date of adopting a State measure may shed light on the question if that measure constitutes an advantage for the purposes of Article 107(1) TFEU. In this case, the EC was right to take into account information relating to events prior to the date of Hungary's EU accession.

The GC thus erred in law, refusing to consider Dunamenti Erőmü's arguments on the sole ground that the privatization took place before the date of Hungary's EU accession ${ }^{22}$. However, this did not lead to the annulment of the GC's judgment since its operative part was well founded even with this error $^{23}$.

\section{The subject of the recovery order}

The case raised a delicate issue where the CJ had to reconcile two of its diverging jurisprudential lines. The Commission's position, based on Germany $v$ Commission ${ }^{24}$, was that the unlawful aid should be recovered from the undertaking sold; Dunamenti Erőmú relied on Banks ${ }^{25}$ to argue that the seller provided that the undertaking which benefited from the aid was sold on market terms.

Dunamenti Erőmű argued that even if an advantage had been granted to it before its privatisation, its purchaser reimbursed the Hungarian State for that advantage since the PPA was included in the price paid by the purchaser to the State. The CJ held in Banks that, "in principle, where a company which has benefited from aid has been sold at a market price, the purchase price reflects the consequences of the previous aid, and it is the seller of that company that keeps the benefit of the aid. In that case, the previous situation is to be restored primarily through repayment of the aid by the seller".

On the other hand, the Commission relied on Germany $v$ Commission where the CJ had held that normally it is not the buyer but the undertaking retaining the competitive advantage connected with that aid that shall repay it. That is so provided the undertaking to which unlawful State aid was granted retains its legal personality and continues to carry out the activities subsidised by the State aid ${ }^{26}$.

22 Para. 107.

23 Judgments in Lestelle v Commission, Case C-30/91 P, ECLI:EU:C:1992:252, para. 28, and FIAMM and Others $v$ Council and Commission, Cases C-120/06 P and C-121/06 P, ECLI:EU:C:2008:476, para. 187 and the case-law cited.

24 Case C-277/00, ECLI:EU:C:2004:238.

25 Case C-390/98, ECLI:EU:C:2001:456.

26 It should be noted that most sale contracts stipulate that the seller guarantees the liabilities of the company sold. In such case, the company sold will be liable to repay any unlawful aid and the clause guaranteeing its liabilities will give the purchaser recourse against 
AG Wathelet pointed out that these judgments apparently propound contradictory views ${ }^{27}$. The only point on which they concur is that the purchaser cannot be held liable to repay the aid ${ }^{28}$. In trying to reconcile the two rulings, the AG recalled that although the judgment in Germany v Commission was adopted later than Banks, it was handed down by a chamber of five judges while the judgment in Banks was handed down by a bench of 11 judges (the Grand Chamber at the time) and has subsequently been cited on a number of occasions. Even after its Germany $v$ Commission ruling, the CJ left the possibility open of recovering the aid either from the seller or from the undertaking sold, without proposing a criterion for deciding which of the two options might be appropriate ${ }^{29}$.

AG Wathelet took the position that recovery of the aid must follow the advantage, in the sense that the entity which has benefited, or continues to benefit from the advantage must repay it whether there was a sale of assets or a sale of shares ${ }^{30}$. The aid must thus be recovered from Dunamenti Erőmü rather than from the seller, in this case MVM or the Hungarian State.

The CJ emphasized that the main purpose of the repayment of unlawful State aid is to eliminate the distortion of competition caused by the unlawful aid $^{31}$. The CJ has consistently held that where an undertaking (which had benefited from unlawful State aid) is bought at a market price, the aid element was assessed at a market price and included in the purchase price. It was held in Germany $v$ Commission that the buyer cannot be regarded as having benefited from an advantage in relation to other market operators ${ }^{32}$. If the beneficiary of the unlawful State aid retains its legal personality and continues to carry out the activities subsidized by the State aid, it is normally this undertaking that must repay an amount equal to that advantage ${ }^{33}$. Even if that company was sold by the State to Electrabel at a market price, and that price fully reflected the value of the advantage resulting from the PPA,

the seller. The matter will then be decided in accordance with the applicable contractual rules, rather than in the context of a recovery procedure.

27 AG Sharpston attempted to explain the discrepancy between these judgments by reference to the fact that Banks concerned the sale of shares while Germany v Commission set out the precedence to be applied for the sale of assets. AG Wathelet did not follow this line of argument.

28 Opinion, 144.

29 Opinion, 147, quoting Commission v France (Case C-37/14, ECLI:EU:C:2015:90), and Falck and Acciaierie di Bolzano v Commission, Cases C-74/00 P and C-75/00 P, ECLI:EU:C:2002:524, para. 180.

30 Opinion, 156.

31 Para. 111, referring to Germany v Commission (Case C-277/00, ECLI:EU:C:2004:238, para. 76).

32 Case C-277/00, ECLI:EU:C:2004:238, para. 80 and the case-law cited.

33 Para. 113. 
Dunamenti Erőmú still retained the advantage of the PPA as it applied starting from 1 May 2004. According to the CJ, the GC did not err in law when it sided with the Commission.

\section{Other related litigations: the ICSID dispute and actions for damages}

In 2007, Electrabel initiated arbitration proceedings against Hungary before the International Centre for Settlement of Investment Disputes (hereinafter, ICSID $)^{34}$. Electrabel claimed, among other things, that by terminating the PPAs without providing full compensation for stranded costs, Hungary had breached the obligations of fair and equitable treatment of investments. The latter are covered by Article 10 of the Energy Charter Treaty of 17 December 1994 (hereinafter, ECT), to which the Kingdom of Belgium, Hungary and the EU are contracting parties to, and which entered into force in April 1998. The ECT contains provisions protecting foreign investments in the energy sector providing protection against expropriation and fair and equitable treatment of foreign investors, etc.

The Commission intervened as a non-disputing party in these proceedings. Its general concern was that compensations awarded as a result of a tribunal decision should not neutralize the effects of its State aid decisions that impose the duty to recover unlawful State aid ${ }^{35}$. The concern lies in the fact that an EC decision ordering the reimbursement of a State aid would be made ineffective if the Member State was obliged to pay the same or similar amount back in the form of compensation to foreign investors. Tamás Kende argues that as a rule, an investment award itself, and subsequently, the enforcement of an investment award, does not generally constitute illegal State aid under Article 107 TFEU because the payment of compensation is involuntary (Kende, 2015, p. 43) ${ }^{36}$.

The Arbitral Tribunal held that the ECT could not protect a European investor from a Member State's enforcement of a binding EC decision. If the provisions of EU law and that of the ECT contradict each other, the Arbitral Tribunal considered that, pursuant to Article 307 CE, (i) the ECT would apply

${ }^{34}$ Electrabel S.A. $v$ The Republic of Hungary, ICSID Case No. ARB/07/19.

35 See. e.g. cases SA.38517(2014/C) (ex 2014/NN) - Romania Implementation of Arbitral award Micula v Romania, 11 December 2013; http://ec.europa.eu/competition/state_aid/cases/ 254586/254586_1595781_31_11.pdf (20.07.2016).

36 Citing (Tietje and Wackernagel, 2014, p. 3), referring also to Asteris, joint Cases 106 to 120/87, ECLI:EU:C:1988:457 (explaining that damages which the national authorities may be ordered to pay to individuals in compensation for damage they have caused to those individuals do not constitute aid). 
when it comes to relations between EU Members and non-EU Members but that (ii) EU law would prevail over the ECT in relations between EU Members themselves. The Arbitral Tribunal dismissed Electrabel's expropriation claim. The Tribunal considered that an "expropriation" implied a radical deprivation of rights or a destruction of an investment, its value or use. In the Tribunal's opinion, Electrabel's investment in Dunamenti remained intact. Hungary could not be held liable for acts committed by the European Commission. Although the termination of the PPA was considered lawful under the ECT, the Arbitral Tribunal found that there was a significant lack of symmetry in the stranded costs compensation scheme amounting to an infringement of the fair and equitable treatment standard ${ }^{37}$. However, given that the final amount of Dunamenti Erőmü's and Electrabel's net stranded costs cannot be calculated until after 31 December 2015, the Arbitral Tribunal decided to reserve its decision to the quantum phase of the proceedings as to whether the scheme for the compensation of stranded costs implemented by Hungary infringed Article 10 ECT. Nevertheless, the Arbitral Tribunal indicated that the nonpayment of HUF 22,171,991,000 or a lesser sum at the end of Hungary's legislative scheme did not strike the Tribunal as necessarily amounting to a breach of the fair and equitable treatment standard. However, non-payment (in cash or otherwise) of a significantly higher sum for Net Stranded Costs most probably could ${ }^{38}$.

Dunamenti Erőmű and Electrabel brought also an action for damages before the GC relying on the second paragraph of Article 340 TFEU, requesting compensation for the loss allegedly suffered as a result of the adoption of the contested EC decision. In November 2014, the GC dismissed that action as inadmissible on the ground that it was time-barred ${ }^{39}$.

37 See Stibbe Newsletter of 04.01.2013, "EU Member State not liable towards EU Investor under the Energy Charter Treaty?”, available at: http://www.stibbe.com/en/news/2013/ january/bru-energy-energy-ebulletin-jan-2013-eu-member-state-not-liable-towards-eu-investor (20.07.2016).

38 That does not appear to have been the approach of the Arbitral Tribunal in the similar Électricité de France (EDF) case. EDF was a shareholder in Budapesti Erőmü. In connection with the termination of its PPA, Hungary was ordered to pay EDF EUR 107 million. See Thomson, D., EDF wins claim against Hungary, published on 11 December 2014, available at: http://globalarbitrationreview.com/news/article/33251/edf-wins-claim-against-hungary/ (20.07.2016).

39 Order of the GC of 13.11.2014, Case T-40/14, ECLI:EU:T:2014:1004. Later, the plaintiffs withdrew their appeal in case C-32/15 P; order of the Court of 25.02.2016, ECLI:EU:C: 2016:197. 


\section{Evaluation of the case}

Long term PPAs pose various competition policy problems. Since they are often concluded between market players with significant market power, they may result in market foreclosure and thus the postponing of the beneficial effects of market liberalization. In addition to Articles 101 and 102 TFEU, State aid rules also have a role to play if the buyer is a publicly owned undertaking. The Commission decided in 2008 that the Hungarian PPAs, concluded at the dawn of the nationwide privatization of the Hungarian energy sector, benefited electricity producers. The fact was of key importance here that the publicly owned MVM was obliged to pay a price calculated on the basis of a formula that a market economy investor would not have agreed to.

The decision of the Commission ordering the return of the aid was not unexpected. Policy papers issued by the Hungarian Competition Authority had warned as early as 1999 and 2002 that long-term purchasing agreements concluded between powerful undertakings may well infringe European competition rules. Similar long-term agreements (extending until 2027) covering $40 \%$ of the Polish energy market, were found to be unlawful State aid as well ${ }^{40}$. A year earlier, in its Energy Sector Inquiry, the Commission assessed the effects of PPAs on the internal market ${ }^{41}$ and concluded that "(l)ong-term power purchase agreements (PPAs) are another factor which may affect the volumes that are traded on a regular basis on wholesale markets" ${ }^{2}$. With regard to the PPAs in Poland, the EC argued that "they may well constitute a significant barrier to the development of the Polish wholesale market". It went on to say that "(a) similar situation exists in Hungary, where Magyar Villamos Muvek ("MVM") is the public utility wholesaler and acquires electricity by means of long-term PPAs that is subsequently sold to the local retailers. The Hungarian PPAs cover the vast majority of the Member State's electricity needs, which may have effects on wholesale trading similar to, or even going further than, those described above in the context of the Polish wholesale market".

Despite all these related events, this was a major decision that made it clear that Hungary belonged now to the European Union where strict rules on competition prevail. In the end however, the EC decision that went against the State aid did not result in huge cash transfers from the electricity generators back to the Hungarian State. Following complex and time consuming

40 NN/99/2005, Brussels, 25.IX.2007 C (2007) 4319 final, available at: http://ec.europa.eu/ competition/state_aid/cases/202115/202115_763547_94_1.pdf (20.07.2016).

41 Published on 10.01.2007; available at: http://ec.europa.eu/comm/competition/antitrust/ others/sector_inquiries/energy/ (20.07.2016).

42 Recitals 467 to 473. 
calculations, the conclusion was reached that the same companies that were now meant to return the State aid would have at the same time been entitled to compensation for their stranded costs resulting from unforeseen sectorial liberalization. These compensations were then "traded in" for the State's recovery obligations resulting from the EC decision. Ultimately, the Hungarian State arrived at a zero amount - hence, no recovery. Still, some companies litigated the case both before EU courts and international tribunals.

This decision is one of those rare cases when the EC intervened to change the effects of State measures that had been taken before Hungary joined the EU. As a rule, State aid carried on into the Union by a new Member State becomes existing aid. Importantly, in contrast with new aid, incompatible existing aid should be terminated for the future, and so a decision going against State aid would not include a burdensome recovery order. However, Central and Eastern European countries had to face more stringent conditions if they wanted to become members of the "Club". Existing Member States wanted to protect the internal market against State measures introduced in the candidate countries before their EU accession. These measures were made subject to, starting from 1 May 2004, EU rules relating to new aid, if those measures did not come within the exceptions specifically listed in the aforementioned annex. It has to be said that this unusual legal framework was not warranted. It is certainly true that the Europe Agreements' State aid-related provisions, mirroring European competition law provisions, did not have direct effect. Also, they did not establish the same level playing field as if the candidate countries were Member States. Yet, even if the general rules of the Regulation implementing Articles 107-108 TFEU had been followed, existing aid could have been terminated by the Commission. In other words, old Member States could have achieved the phasing out of those aid measures which distorted competition to the detriment of their companies.

Cases focusing on measures adopted in the distant past often raise issues relating to which law is to be applied and the events of which time period should be taken into account. In this case, the time factor was further complicated by EU accession, part of the PPAs' life time being before, part of it after 1 May 2004.

AG Wathelet was persuaded by the plaintiff's arguments that the Commission and the GC should have travelled back in time to the date when the PPAs had first been agreed upon. The CJ did not follow this path but ruled instead that the reference period for evaluating the State aid cannot be earlier than the date of Hungary's EU accession. According to the CJ, the Commission was right to believe that this is the right approach, also in cases where a measure became State aid only years after its actual adoption (here as a result of Hungary becoming a part of the liberalized EU energy market). 
It should be noted that the EC also ordered the recovery of aid still existing after the accession date. The investigation did not cover those measures which ceased to exist before 1 May 2004.

Emanuela Matei argues that it is unfortunate for the CJ not to draw the logical consequences of its well established economic unit doctrine ${ }^{43}$. Dunamenti Erőmü, the acquired entity, was regarded as the actual beneficiary of the State aid while Electrabel was presented as a separate entity, even though it held a $75 \%$ controlling stake in the electricity producer. From the perspective of a private investor such as Electrabel, the benefit of the PPA covering a time horizon of 15-20 years was sure to have played a role in its decision to acquire the Hungarian operator. It is hard to believe that the price paid by Electrabel in 1995 did not cover the value of the PPAs. Hence the Commission should have assessed the matter whether the price paid by Electrabel took into account the PPAs as part of the MEIP test. The CJ did not follow the opinion of its AG on this point.

It is certain that without the long term PPAs foreign companies would have been less interested in purchasing Hungarian electricity producers only a couple of years after the collapse of its socialist regime. The conclusion of the PPAs by the publicly owned MVM might have been compatible with the long-term strategy of a private investor. Furthermore, even if aid had been granted to the producers, their subsequent privatization price should have reflected the following - without the PPAs, the price paid by foreign investors should have been lower. In other words, the price of the aid was paid by the new owners. Yet to prove this theory to the requisite high standard after so many years is extremely demanding, if not impossible.

There is a further factor strengthening the Commission's strict interpretation. The PPAs original timeframe was extended before Hungary's EU accession for an additional couple of years. The plaintiff may have argued that the value of the 15-year long PPA was considered in the purchase price. This is not true, however, for the extra years. This advantage could not have been properly remunerated when the company was privatized.

Another noteworthy point of the case was that, as pointed out by AG Wathelet, the jurisprudence of the CJ was somewhat inconsistent as to which company must repay the aid if the undertaking was meanwhile sold. The CJ did not hesitate to confirm its Germany $v$ Commisson ruling providing that if the beneficiary of the unlawful State aid retains its legal personality and continues to carry out the activities subsidized by the State, as Dunamenti Erőmü did, it is normally this undertaking that must repay the advantage.

43 E. Matei, A new misnomer in State aid law: single economic unit with separate legal personality (C 357/14 P, Dunamenti Erömü/Commission), 22.10.2015, available at: http:// stateaidhub.eu/blogs/stateaid/post/3945 (20.07.2016). 
From a procedural point of view, it was also interesting to realize the limits of the wide concept of an undertaking. A company that was not a party in the first instance judicial procedure was not allowed to appeal the GC's judgment even if, at the time when the case was registered, it formed an economic unit with the undertaking to which the Commission's decision was addressed.

\section{Literature}

Kende, T. (2015). Arbitral Awards Classified as State Aid under European Union Law. ELTE Law Journal, 1.

Tietje, C. and Wackernagel, C. (2014). Outlawing Compliance? - The Enforcement of intra-EU Investment Awards and EU State Aid Law. Policy Papers on Transnational Economic Law, 41. 